\title{
New perspectives of mental health service research Nuove prospettive della ricerca sui servizi per la salute mentale
}

\section{F. Amaddeo*, Guest Editor and M. Tansella, Editor}

Epidemiology in the field of mental health is facing new challenges and is now tracing new perspectives. A wide literature is available to explain how psychiatric illnesses are distributed and scientific articles have contributed to hypotheses about which factors influence the distribution of these conditions (Alonso et al. 2007; Lund et al. 2010).

Nevertheless, we remain unable to predict mental health service utilisation and their costs. After a person is diagnosed with a mental disorder, her/his behaviour, and the consequent access to and utilisation of services, are influenced by a complex variety of interacting factors. Some of these factors have been explored using innovative epidemiological approaches; in particular, researchers are interested in the interaction between individual and environmental characteristics. The components of the environment where patients live are, for example, the social milieu, the availability and accessibility of health services and the organisation of social and health services that are mainly based on political choices. To investigate these complex models, studies have to be conducted comparing different places, linking together data from different settings of care, and using health geographic techniques such as Geographic Information Systems. For example, they can be conducted at the international level or by comparing large regions within one same country, and by using data from social, general health (including primary care), mental health and other specialty sectors.

Very few of such studies have been carried out until now, and all of them have recognised methodological difficulties and biases that affect their results. These studies have highlighted that, in areas where care is provided by community-based systems, social and economic characteristics of the place of residence are associated with psychiatric service use by patients. However, socio-economic status and distance from hospital or other community-based services should not prevent the access to the care, but for some types of care (e.g. day care) there is a relation between

* Address for correspondence: Professor Francesco Amaddeo, Department of Public Health and Community Medicine Section of Psychiatry and Clinical Psychology Ospedale Policlinico "G.B. Rossi" P.le L.A. Scuro, 10, 37134 Verona, Italy.

(Email: francesco.amaddeo@univr.it) service utilisation and proximity between place of residence and services (Zulian et al. 2011). Moreover, accessibility is a many-sided concept that considers many factors, such as the cost of the travel, the availability of public transport, psychological and physical barriers, social and cultural factors and environment characteristics, as well as social capital and social cohesion.

Another important issue for psychiatric epidemiology is to find strong and widely agreed indicators of the quality of care provided by mental health services. One of these, even if open to criticism and not exhaustive, is the excess of mortality, and of avoidable mortality, among users of mental health services. In a study conducted in Verona (Italy), the observed number of deaths from avoidable causes among users of community-based mental health services was shown to be four times greater than expected. The standardised mortality ratio (SMR) is higher for deaths preventable with adequate health promotion policies than for those preventable with appropriate health care. Males, alcohol/drug-addicted and younger patients had the highest mortality. From these results, it seems important that the implementation, by specialist psychiatric services, of health promotion and preventive programs specifically targeted psychiatric patients (Amaddeo et al. 2007; Grigoletti et al. 2009; Amaddeo \& Tansella, 2010).

If, on one hand, it is complex to conduct studies at the international level, on the other hand, this is the only way to obtain answers to the research questions that will allow in the future greater understanding and, as a consequence, improved quality of mental health services.

In this issue of Epidemiology and Psychiatric Sciences, we have asked the leading researchers who are involved in important European comparative projects to write three Editorials that consider different aspects of research in the field of mental health services.

The first one, written by Heinz Katschnig (2011), explains how difficult the exercise of mapping pathways of care of persons with mental disorders is. It is not yet possible to compare in a conclusive way different health-care systems in terms of their relative performance and efficiency as there is no agreement on categories and indicators, and international comparisons are still dominated by contrasting simple 
'indicators', such as mortality rates, staffing ratios or hospital episodes. Overcoming these methodological problems will allow us to answer many important questions related to the effects of interventions in the health-care systems on service utilisation by specific groups of patients, the influence of different healthcare and financing systems in different regions or countries on service utilisation by specific groups of patients, and the calculation of comprehensive and real costs of service utilisation (e.g. by identifying duplication of service use) by specific groups of patients and monitor them over time. The author stresses the value of data linkage at different levels of mental health care, general hospitals, primary care and social services. To reach this goal the development of a 'unique patient identifier' is crucial as it is now possible to use pseudo-anonymisation techniques to protect individuals' privacy.

The second Editorial is written by Kristian Wahlbeck (2011) and deals with the issue of international comparisons, in particular in EU countries. International benchmarking, based on comparable data, is an important moving force for development of mental health services in countries. The author reports the efforts of European institutions such as WHO Regional Office for Europe, OECD or the European Commission to build reliable and comparable databases. The European Community Health Indicators (ECHI) project is described in detail as well as the work undertaken also to include in this project mental health indicators covering mental health system resources, mental health care utilisation and expenditure on mental health services.

The third Editorial, by Luis Salvador-Carulla \& Patricia Hernández (2011), reports on experiences in

Nel campo della salute mentale, l'epidemiologia sta affrontando nuove sfide e tracciando nuove prospettive. Un'ampia letteratura è oggi disponibile per spiegare come le patologie psichiatriche sono distribuite e un certo numero di articoli scientifici hanno contribuito a ipotizzare quali fattori influenzano questa distribuzione (Alonso et al. 2007; Lund et al. 2010).

Nonostante ciò, non siamo ancora in grado di prevedere l'utilizzazione ed i costi dei servizi per la salute mentale. Dopo che una persona riceve una diagnosi di un disturbo mentale, il suo comportamento, ed il conseguente accesso ed utilizzazione dei servizi, è influenzato da una complessa varietà di fattori che interagiscono tra di loro. Alcuni di questi fattori sono stati studiati usando approcci epidemiologici innovativi; in particolare, i ricercatori sono interessati all'interazione tra individuo e caratteristiche dell'ambiente. Le componenti dell'ambiente dove il paziente vive sono, recent years about international studies in the mental health economics context. All the reported economic studies faced the same difficulties indicated by the first two Editorials, the lack of a basic standard system and terms for gathering this information to constitute a useful knowledge base to facilitate information transfer in Europe. The authors trace out a route that should be followed to overcome these difficulties particularly in mental health economics studies. For example, consensus should be initiated by setting the scope of the mental health field, as to which entities to include, how to deal with the associated social services and what non-health services to consider. Measurement strategies should indicate the various relevant reporting layers to compare at national and international levels.

The Editorials cited the REFINEMENT project. This is a research project funded by EU that will start in January 2011, coordinated by the Section of Psychiatry and Clinical Psychology, Department of Public Health and Community Medicine, at the University of Verona (Italy) and will involve nine European Countries (Austria, Estonia, Finland, France, Italy, Spain, Norway, Romania and United Kingdom) with the aim to explore the effects of funding systems on the quality of care in mental health. This will be obtained through six work packages focused on: (1) financing systems for mental health care, (2) functional and dysfunctional financial incentives, (3) mapping services for mental health care, (4) identifying and interpreting pathways of care, (5) quality of mental health care and met/ unmet needs for care and (6) building best practice models of mental health-care financing. The project will propose methodological approaches to overcome the problems described in the Editorials.

per esempio, il clima sociale, la disponibilità e l'accessibilità dei servizi sanitari, l'organizzazione dei servizi sociali e sanitari che è principalmente basata su scelte politiche. Per analizzare modelli così complessi, gli studi dovrebbero essere condotti confrontando posti diversi, mettendo insieme dati provenienti da diversi setting di assistenza ed usando tecniche della geografia sanitaria (come i GIS). Per esempio, dovrebbero essere condotti a livello internazionale o confrontando ampie regioni dello stesso paese, ed utilizzando dati provenienti dal settore sociale, sanitario in generale (inclusa la medicina di base), dei servizi di salute mentale e da altri settori specialistici.

Pochi studi di questo tipo sono stati condotti finora e tutti hanno dichiarato le difficoltà metodologiche e gli errori che sono contenuti nei loro risultati. Questi studi hanno dimostrato che, in aree dove l'assistenza è garantita da un sistema community-based, le caratteristiche 
sociali ed economiche del luogo di residenza sono associate con l'uso dei servizi psichiatrici da parte dei pazienti. Lo status socio-economico e la distanza dall'ospedale o dai servizi territoriali non dovrebbero impedire l'accesso alle cure, invece per alcuni tipi di servizio (per esempio, i centri diurni) esiste una relazione tra utilizzazione dei servizi e vicinanza tra luogo di residenza e servizio (Zulian et al. 2011). Inoltre, l'accessibilità è un concetto con diverse sfaccettature che riguarda diversi fattori, come il costo dei trasporti, la disponibilità di mezzi pubblici, le barriere psicologiche e fisiche, fattori culturali e sociali e caratteristiche dell'ambiente, così come il capitale sociale e la coesione sociale.

Un altro importante problema per l'epidemiologia psichiatrica è quello di trovare indicatori forti e ampiamente condivisi della qualità dell'assistenza fornita dai servizi per la salute mentale. Uno di questi, seppur criticabile e non esaustivo, potrebbe essere l'eccesso di mortalità, e di mortalità "evitabile", tra coloro che usano i servizi di salute mentale. In uno studio condotto a Verona (Italy), è stato dimostrato che il numero di morti per cause evitabili tra gli utenti di un servizio psichiatrico community-based è quattro volte maggiore dell'atteso. Lo Standardised Mortality Ratio (SMR) è maggiore per quei decessi che sono prevenibili con adeguate politiche di promozione della salute piuttosto che attraverso politiche di adeguata assistenza sanitaria. I maschi giovani, con problemi di dipendenza da alcool e droghe, hanno i livelli più elevati di mortalità. Questi risultati dimostrano l'importanza, da parte dei servizi specialistici psichiatrici, di implementare programmi di promozione e prevenzione specificamente diretti ai pazienti psichiatrici (Amaddeo et al. 2007; Grigoletti et al. 2009; Amaddeo \& Tansella, 2010).

Se, da un lato, per molte ragioni è complesso condurre studi a livello internazionale, d'altra parte, questa è l'unica via per ottenere risposte alle domande di ricerca che permetteranno in futuro di progredire nella conoscenza e, di conseguenza, di migliorare la qualità dei servizi per la salute mentale.

In questo numero di Epidemiology and Psychiaric Sciences abbiamo chiesto a ricercatori leader impegnati in importanti progetti di ricerca comparativa europea di scrivere tre Editoriali che affrontano diversi aspetti nel campo della ricerca sui servizi per la salute mentale.

Il primo, scritto da Heinz Katschnig (2011), spiega quanto difficile sia l'esercizio di descrivere i percorsi di cura delle persone con disturbi mentali e quali iano le possibili soluzioni per rendere ciò possibile in studi comparativi internazionali. Non è ancora possibile confrontare, in modo esaustivo, diversi sistemi assistenziali in termini di performance relative ed efficienza così come non $c^{\prime} \mathrm{e}^{\prime}$ accordo sulle categorie e sugli indicatori. I confronti internazionali sono ancora dominati da indicatori semplici e divergenti, come ad esempio i tassi di mortalità, il rapporto tra personale ed utenti o i ricoveri ospedalieri. Superare questi problemi metodologici permetterebbe di rispondere a molte importanti domande relative agli effetti degli interventi nei sistemi sanitari sull'utilizzazione dei servizi da parte di specifici gruppi di pazienti, all'influenza di diversi sistemi di finanziamento in diverse regioni o paesi sull'utilizzazione dei servizi da parte di specifici gruppi di pazienti, e al calcolo completo e reale dei costi dell'utilizzazione dei servizi (per esempio, identificando la duplicazione dell'uso dei servizi) da parte di specifici gruppi di pazienti, anche monitorandoli nel tempo. L'Autore sottolinea il valore della possibilità di collegare i dati a diversi livelli dell'assistenza psichiatrica, dell'ospedale generale, della medicina di base e dei servizi sociali. Per raggiungere questo obiettivo, è cruciale lo sviluppo di un "codice identificativo unico" dato che è oggi possibile usare tecniche di anonimizzazione (pseudonymisation) dei dati per proteggere la privacy individuale.

Il secondo Editoriale è stato scritto da Kristian Wahlbeck (2011) e affronta il problema dei confronti internazionali in particolare nei paesi dell'Unione Europea. Il benchmarking internazionale, basato su dati confrontabili, è un importante spinta per lo sviluppo dei servizi per la salute mentale nelle diverse nazioni. L'Autore riporta gli sforzi di istituzioni europee, come l'OMS (Regional Office for Europe), l'OCSE e l'Unione Europea, per costruire database affidabili e confrontabili. Il progetto European Community Health Indicators (ECHI) è descritto nei dettagli, così come il lavoro che si sta facendo per includervi indicatori della salute mentale che comprendano le risorse dei servizi per la salute mentale, l'utilizzazione dei servizi di salute mentale e la spesa per tali servizi.

Il terzo Editoriale, di Luis Salvador-Carulla \& Patricia Hernández (2011), riferisce delle esperienze fatte negli ultimi anni sugli studi internazionali sull'economia della salute mentale. Tutti gli studi che vengono descritti hanno dovuto affrontare le stesse difficoltà indicate nei primi due Editoriali, la mancanza di un sistema di base standard e di una terminologia per mettere insieme le informazioni e costituire una base di conoscenze utile per facilitare lo scambio a livello europeo. Gli Autori tracciano una direzione che dovrebbe essere seguita per superare queste difficoltà, particolarmente negli studi di economia della salute mentale. Per esempio, il consenso dovrebbe partire dal definire gli scopi della salute mentale, come anche dire quali entità includere, come affrontare il problema dei servizi sociali associati e quali servizi non-sanitari dovrebbero essere considerati. Le strategie di misurazione dovrebbero indicare quali livelli 
rilevanti devono essere confrontai a livello nazionale ed internazionale.

Gli Editoriali hanno citato il progetto REFINEMENT. Questo è un progetto di ricerca finanziato dalla Commissione Europea che partirà a gennaio 2011, coordinato dalla Sezione di Psichiatria e Psicologia Clinica, Dipartimento di Sanità Pubblica e Medicina di Comunità, dell'Università di Verona (Italia) che coinvolge 9 Paesi Europei (Austria, Estonia, Finlandia, Francia, Italia, Spagna, Norvegia, Romania and Regno Unito) con lo scopo di esplorare gli effetti dei sistemi di finanziamento sulla qualità dell'assistenza alla salute mentale. Ciò sarà ottenuto attraverso 6 work package che si occuperanno di: (1) sistemi di finanziamento per la salute mentale, (2) incentivi finanziari funzionali e disfunzionali, (3) mappatura dei servizi di salute mentale, (4) identificazione ed interpretazione dei percorsi di cura, (5) qualità dell'assistenza per la salute mentale e bisogni di assistenza soddisfatti e non soddisfatti, e (6) costruzione delle migliori pratiche per il finanziamento dei servizi di salute mentale. Il progetto proporrà gli approcci metodologici per superare i problemi descritti in questi tre Editoriali.

\section{References}

Alonso J, Codony M, Kovess V, Angermeyer MC, Katz SJ, Haro JM, De Girolamo G, De Graaf R, Demyttenaere K, Vilagut G, Almansa J, Lépine JP, Brugha TS, The Esemed/ Mhedea 2000 Investigators (2007). Population level of unmet need for mental healthcare in Europe. British Journal of Psychiatry 190, 299-306.
Amaddeo F, Barbui C, Perini G, Biggeri A, Tansella M (2007). Avoidable mortality of psychiatric patients in an area with a community-based system of mental health care. Acta Psychiatrica Scandinavica 115, 320-325.

Amaddeo F, Tansella M (2010). Mortality among people with mental disorders. Epidemiologia e Psichiatria Sociale 19, 1-3.

Grigoletti L, Perini G, Rossi A, Biggeri A, Barbui C, Tansella M, Amaddeo F (2009). Mortality and cause of death among psychiatric patients. A twenty year case-register study in an area with a communitybased system of care. Psychological Medicine 39, 1875-1884.

Katschnig H (2011). Monitoring service utilization by persons with mental disorders - a case for mapping pathways of care. Epidemiology and Psychiatric Sciences 20, 7-13.

Lund C, Breen A, Flisher AJ, Kakuma R, Corrigall J, Joska JA, Swartz L, Patel V (2010). Poverty and common mental disorders in low and middle income countries: a systematic review. Social Science and Medicine 71, 517-528.

Salvador-Carulla L, Hernández-Peña P (2011). Economic context analysis in mental health care. Usability of health financing and cost of illness studies for international comparisons. Epidemiology and Psychiatric Sciences 20, 19-27.

Wahlbeck K (2011). European comparisons between mental health services. Epidemiology and Psychiatric Sciences 20, 15-18.

Zulian G, Donisi V, Secco G, Pertile R, Tansella M, Amaddeo F (2011). How are caseload and service utilisation of psychiatric services influenced by distance? A geographical approach to the study of community-based mental health services. Social Psychiatry and Psychiatric Epidemiology (in press). 